\title{
15. MINERALOGY OF SEDIMENTS ENCOUNTERED DURING DEEP SEA DRILLING PROJECT LEG 69 (COSTA RICA RIFT, PANAMA BASIN), AS DETERMINED BY X-RAY DIFFRACTION ${ }^{1}$
}

\author{
Helmut Beiersdorf and Heinrich Rösch, Bundesanstalt für Geowissenschaften und Rohstoffe, \\ D-3000 Hannover 51, Federal Republic of Germany
}

\begin{abstract}
We discuss the provenance of minerals detected by X-ray-diffraction analyses of sediments of Sites 504 and 505 of Deep Sea Drilling Project Leg 69. These are X-ray-amorphous material, opal-CT, calcite, quartz, feldspar, apatite, smectite, illite, kaolinite, magnetite, maghemite, pyrite, marcasite, barite, sepiolite, and clinoptilolite. Authigenic marcasite and clinoptilolite together with opal-CT are restricted to Site 504, indicating the special diagenetic conditions related to relatively high sediment temperatures at this site. Marcasite formation is likely dependent on the relatively low $\mathrm{pH}$ values of $<7.1$ found in interstitial waters of Site 504 sediments below 50 meters sub-bottom. Clinoptilolite evidently was formed by diagenetic alteration of rhyolitic volcanic glass or smectite plus biogenic silica within the chalk-limestone-chert sequence of Site 504, where opal-CT also reflects a high degree of silica dissolution and reprecipitation. This was a consequence of high temperatures $\left(50-55^{\circ} \mathrm{C}\right)$ at the base of the sediment column.
\end{abstract}

\section{INTRODUCTION}

A total of 63 samples of sediments from Sites 504 and 505 of DSDP Leg 69 were taken for X-ray-diffraction analysis in order to identify mineral phases which were not detectable by petrographic investigations of smear slides and thin-sections.

The samples came from all lithologic units of the sedimentary columns of both sites (Figs. 1 and 2; Table 1), ranging in age from late Pleistocene to late Miocene at Site 504, and late Pleistocene to early Pliocene at Site 505. The sites are located at $1^{\circ} 13.6^{\prime} \mathrm{N}, 83^{\circ} 43.9^{\prime} \mathrm{W}$ and $1^{\circ} 54.82^{\prime} \mathrm{N}, 83^{\circ} 47.39^{\prime} \mathrm{W}$ respectively.

The unit boundaries at Site 504 are diagenetic boundaries. Unit I ( $0-143.50 \mathrm{~m})$ consists of variably clay-bearing siliceous nannofossil and nannofossil radiolarian oozes; Unit II (143.50-227.20 m) is represented by siliceous nannofossil chalk; and Unit III (227.20-271 m) comprises interbedded nannofossil chalk, limestone, and chert. Unit I of Site $505(0-14.50 \mathrm{~m})$ is calcareous marl; Unit II (14.50-133.50 m) consists of variably clay-bearing nannofossil siliceous oozes; and Unit III (133.50-232 $\mathrm{m})$ is siliceous nannofossil ooze.

The interval from 65 to 99 meters (Sub-unit IB) at Site 504 shows significant changes in composition, texture, and coloration in conjunction with an increased manganese-oxide content. Therefore, sampling intervals are smaller for this part of the sequence than for other parts.

\section{ANALYTICAL METHODS}

Calcium carbonate was determined volumetrically in seven samples and compared with the $\mathrm{CaCO}_{3}$ contents of the respective core intervals derived from volumetric measurements during Leg 69 (Beiersdorf and Natland, this volume). The agreement between both sets of measurements was generally good and showed absolute deviations of only about $5 \%$ (Fig. 1). Therefore, the volumetrically measured

\footnotetext{
${ }^{1}$ Cann, J. R., Langseth, M. G., Honnorez, J., Von Herzen, R. P., White, S. M., et al., Init. Repts. DSDP, 69: Washington (U.S. Govt. Printing Office).
}

data obtained during the leg were used for the calculation of the bulk composition.

To evaluate the significance of certain sediment components with regard to grain size, all samples were divided into the grain-size fractions $<2 \mu \mathrm{m}, 2$ to $20 \mu \mathrm{m}$, and $>20 \mu \mathrm{m}$. The sum of the weight percentages of the three carbonate-free grain-size fractions plus the $\mathrm{CaCO}_{3}$ weight percentages obtained from the $\mathrm{CaCO}_{3}$-distribution curve were recalculated to $100 \%$ (Table 1 ).

The non- $\mathrm{CaCO}_{3}$ components were determined qualitatively from glycolated powder samples of the individual grain-size fractions by X-ray-diffraction analyses with an automatic Philips-APD $10 \mathrm{X}$-ray diffractometer equipped with a graphite monochromator and an automatic divergence slit system. The concentration of some of the important components was estimated from peak height measurements on selected diffraction peaks. The peak heights then were compared with those of pure standards of the individual minerals. Implicitly the mass-absorption coefficients were taken into consideration by measuring the incoherent Compton. radiation with a second detector at high $\vartheta$-angles. The concentration of the individual components was then calculated by using the formula:

$$
x=\frac{k_{2}}{k_{1}} \text {, where } k_{1}=\frac{I_{d 1}}{I_{c 1}} \text {, and } k_{2}=\frac{I_{d 2}}{I_{c 2}}
$$

(see, e.g., Sahores, 1972), in which $I_{d 1}, I_{d 2}$ are background-corrected diffraction intensities of pure standard (1) and of the same component in the sample under investigation (2), and $I_{c 1}, I_{c 2}$ are backgroundcorrected Compton intensities of the pure standard (1) and the sample under investigation (2).

In comparison to the internal-standard or the Chung method, this procedure does not require addition of calibration substances, nor does it require the determination of calibration constants. However, since the influences of orientation and other factors (e.g., solid solution, cation substitution, non-identical standards, etc.) in the method applied here are similar to those of other quantitative X-ray-diffraction methods, the results were rounded and checked against a qualitative chart diagram.

Using the procedure described above, we determined the concentrations of the following minerals: quartz, pyrite, barite, dolomite, siderite, opal-CT, goethite, and magnetite/maghemite. The concentration of all other components-especially feldspar and smectite, together with the amorphous scatter-were empirically estimated and balanced to $100 \%$, together with the measured concentrations.

\section{RESULTS}

The X-ray-diffraction results are listed in Table 1 . The significance of the detected minerals in determining 


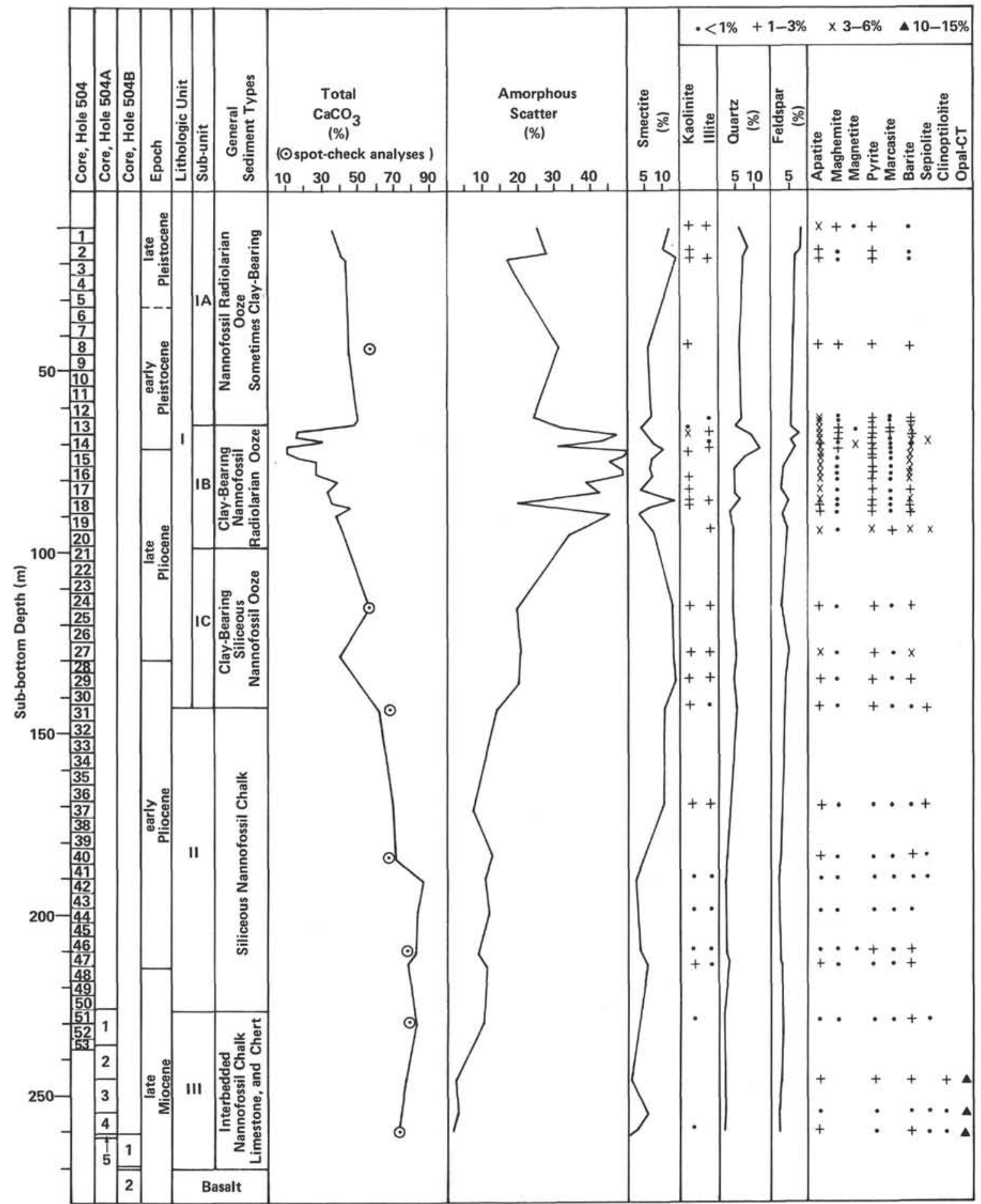

Figure 1. X-ray mineralogy of sediments from DSDP Site 504.

the origin and evolution of the sediment types is discussed below.

\section{Sediment Constituents as Detected by X-Ray-Diffraction Analyses}

The following constituents were detected by X-raydiffraction analyses: (1) X-ray-amorphous material (as indicated by "amorphous scatter"); (2) clay minerals (smectite, kaolinite and illite); (3) quartz and feldspar;
(4) maghemite and magnetite; (5) apatite; (6) pyrite, marcasite, and barite; (7) sepiolite, clinoptilolite, and opal-CT; (8) trace minerals (siderite, talc, amphibole, serpentine-kaolinite, dolomite, goethite).

$\mathrm{X}$-ray amorphous material, smectite, quartz, feldspar, apatite, pyrite, barite, and maghemite are ubiquitous in the unconsolidated sediments of both sites. At Site 504, clinoptilolite and opal-CT occur in Unit III only, where limestones and cherts form significant parts of the sedi- 


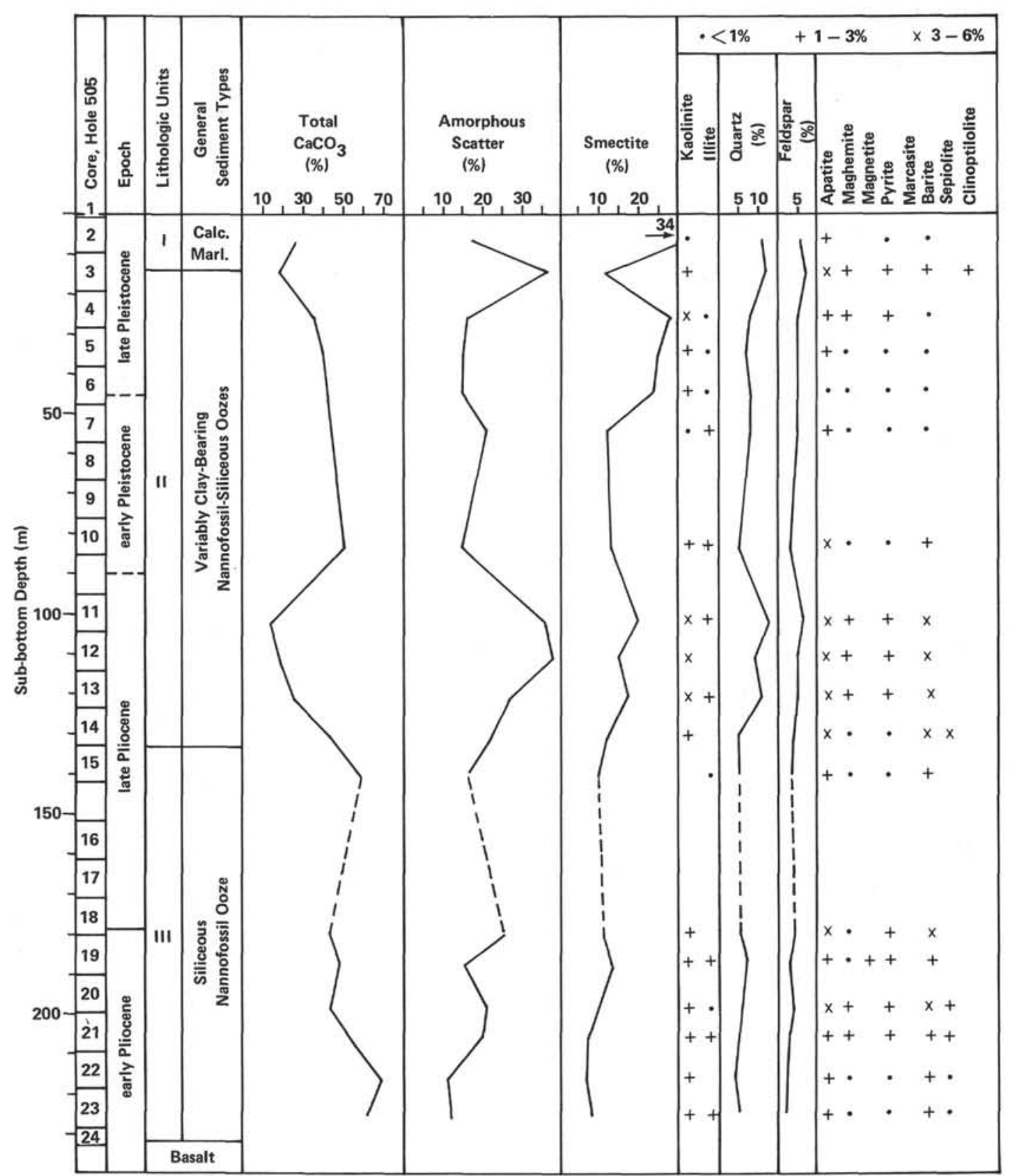

Figure 2. X-ray mineralogy of sediments from DSDP Site 505.

mentary sequences. A single occurrence of clinoptilolite was found in the sediments of Site 505. Marcasite was detected only in Site 504 sediments. Magnetite and sepiolite occurred in a comparatively small number of samples, the magnetite restricted to unconsolidated parts of the sequences. Kaolinite and illite were detected in most of the samples.

\section{Distribution and Possible Origin of Constituents}

\section{Amorphous Material}

The X-ray-amorphous material, indicated by “amorphous scatter" in the diffractograms, consists of material dominantly derived from siliceous microfossils (diatoms, radiolarians, silicoflagellates, and sponge spicules), as microscopic investigations of sediments from both sites have shown (Beiersdorf and Natland, this volume). From these determinations, it also became obvious that volcanic glass, except for ash layers, forms a significant but minor portion of the X-ray-amorphous fractions.

The X-ray-amorphous material occurs in significant quantities in all three grain-size fractions of the unconsolidated sediments of both sites, and (in much smaller quantities) in the $<2-\mu \mathrm{m}$ fraction only in the sediments of Unit III of Site 504. It is the most important constituent of the $>20-\mu \mathrm{m}$ fraction of the unconsolidated sediments, where it often forms more than $50 \%$ of the fraction's composition. The highest amounts of X-ray-amorphous material occur in the late Pliocene sediments of both sites, and in the late Pleistocene sediments of Site 
Table 1. Mineralogical composition of sediment samples from DSDP Sites 504 and 505 in weight percent.

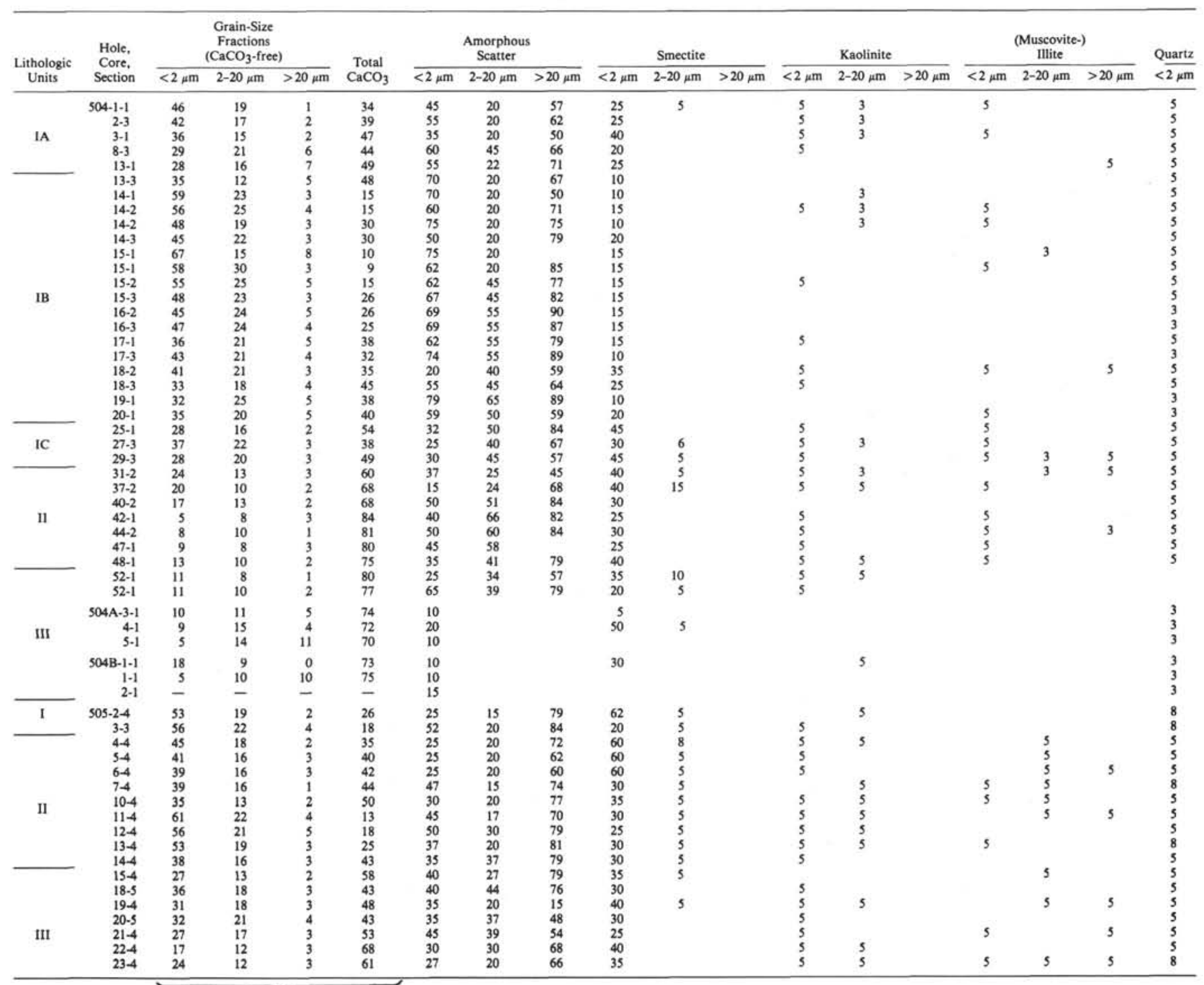

$\Sigma=100 \%$

Note: $\bullet \mathrm{k}=$ kaolinite-sepiolite; $\mathrm{a}=$ amphibole; $\mathrm{t}=$ tale; $\mathrm{s}=$ siderite; $\mathrm{d}=$ dolomite; $\mathrm{g}=$ goethite.

505. Variations in the amount of "amorphous scatter" can be strong, as demonstrated by the densely sampled Sub-unit IB of Site 504 (Fig. 1). However, the "amorphous scatter" distribution curves are in good agreement with the "siliceous fossil" distribution curve, except for Sub-units IB and IC of Site 504, and for the pronounced peak in the "amorphous scatter" curve near the boundary of Units I and II of Site 505. This anomalous behavior will be discussed in the conclusions.

From the top of Sub-unit IC of Site 504 downward there is a general decrease in "amorphous scatter" to percentages lower than 5\% reached in Unit III. At Site 505 this trend is only weakly reflected by the distribution diagram below the late Pliocene peak.

The amount of X-ray-amorphous material in the sediments younger than early Pliocene is generally higher at Site 504 than at Site 505. The higher smectite content of the Site 505 sediments seems to reflect a consumption of opal-A of the siliceous fossils and volcanic glass by smec- tite-forming processes (sensu Johnson, 1976). The strong decrease in "amorphous scatter" in Unit III of Site 504 reflects the diagenetic transformation of skeletal opal-A into opal-CT, quartz, and possibly clinoptilolite.

\section{Smectite}

Smectite is the predominant clay mineral in the sediments of both sites, forming a significant portion of the $<2-\mu \mathrm{m}$ fraction. Unusual occurrences of smectite within the 2- to $20-\mu \mathrm{m}$ fraction in samples of the two sites are thought to be the result of occlusion within microfossil remains (e.g., radiolarians). At Site 504, the smectite percentages are never higher than $15 \%$, whereas at Site 505 this value often is exceeded and reaches a maximum of $34 \%$.

Some of the smectite seems to be terrigenous (see section on kaolinite and illite). The good negative correlation between "'amorphous scatter" and smectite (Fig. 3) suggests that another part of the smectite was formed 
Table 1. (Continued).

\begin{tabular}{|c|c|c|c|c|c|c|c|c|c|c|c|c|c|c|c|c|c|c|}
\hline \multicolumn{2}{|c|}{ Quartz } & \multicolumn{3}{|c|}{ Feldspar } & \multicolumn{3}{|c|}{ Apatite } & \multicolumn{3}{|c|}{ Magnetite } & \multicolumn{3}{|c|}{ Maghemite } & \multicolumn{3}{|c|}{ Pyrite } & \multicolumn{2}{|c|}{ Marcasite } \\
\hline $2-20 \mu \mathrm{m}$ & $>20 \mu \mathrm{m}$ & $<2 \mu \mathrm{m}$ & $2-20 \mu \mathrm{m}$ & $>20 \mu \mathrm{m}$ & $<2 \mu \mathrm{m}$ & $2-20 \mu \mathrm{m}$ & $>20 \mu \mathrm{m}$ & $<2 \mu \mathrm{m}$ & $2-20 \mu \mathrm{m}$ & $>20 \mu \mathrm{m}$ & $<2 \mu \mathrm{m}$ & $2-20 \mu \mathrm{m}$ & $>20 \mu \mathrm{m}$ & $<2 \mu \mathrm{m}$ & $2-20 \mu \mathrm{m}$ & $>20 \mu \mathrm{m}$ & $<2 \mu \mathrm{m}$ & $2-20 \mu \mathrm{m}$ \\
\hline 16 & 5 & 5 & 30 & 10 & 5 & 8 & 8 & & & 15 & & 8 & & & 5 & 5 & & \\
\hline 24 & 5 & 5 & 30 & 10 & & 8 & & & & & & 5 & & & 5 & 20 & & \\
\hline 34 & 3 & 5 & 20 & 10 & & 8 & & & & & & 5 & 5 & & 5 & 24 & & \\
\hline 17 & 3 & 5 & 15 & 15 & & 5 & 3 & & & & & 5 & 5 & & 5 & 8 & & \\
\hline 29 & 3 & 5 & 20 & 5 & 5 & 8 & 5 & & & & & 5 & & & 8 & 8 & & 5 \\
\hline 22 & 5 & 5 & 20 & 10 & 5 & 10 & 5 & & & & & 5 & 5 & & 10 & 8 & & 5 \\
\hline 26 & & 5 & 15 & 20 & 5 & 8 & 5 & & & 10 & & 5 & & & 10 & 15 & & 5 \\
\hline 26 & 5 & 5 & 15 & 8 & 5 & 10 & 3 & & & & & 5 & 3 & & 8 & 10 & & 5 \\
\hline 35 & 5 & 5 & 11 & 10 & & 8 & 5 & & & & & 5 & & & 8 & 5 & & 5 \\
\hline 36 & 3 & 5 & 15 & 5 & 5 & 8 & & & & & & 5 & 5 & & 5 & 8 & & 3 \\
\hline 36 & 10 & 5 & 10 & 5 & & 8 & & & & 65 & & 5 & & & 10 & 15 & & 3 \\
\hline 38 & & 3 & 10 & 5 & 5 & 8 & & & & & & 5 & 5 & & 8 & 5 & & 3 \\
\hline 20 & 3 & 3 & 8 & 15 & 5 & 8 & & & & & & 3 & & & 5 & 5 & & 3 \\
\hline 18 & 3 & 3 & 10 & 5 & 5 & 8 & & & & & & 3 & 5 & & 8 & 5 & & 3 \\
\hline 13 & & 3 & 5 & 5 & 5 & 8 & & & & & & 3 & & & 5 & 5 & & 3 \\
\hline 10 & 3 & 3 & 5 & 5 & 5 & 8 & & & & & & 3 & & & 8 & 5 & & 3 \\
\hline 10 & 3 & 3 & 5 & 5 & 5 & 8 & & & & & & 3 & 5 & & 8 & 8 & & 3 \\
\hline 13 & 3 & 3 & 5 & 3 & 5 & 5 & & & & & & 3 & & & 8 & 5 & & 3 \\
\hline 15 & 3 & 5 & 10 & 3 & 5 & 8 & & & & & & 3 & & & 10 & 25 & & 3 \\
\hline 13 & 3 & 5 & 10 & 3 & & 8 & & & & & & 3 & 5 & & 10 & 20 & & 3 \\
\hline 7 & 3 & 3 & 5 & 3 & & 5 & & & & & & 3 & & & 5 & 5 & & 5 \\
\hline 12 & 3 & 3 & 6 & 3 & 5 & 8 & & & & & & 3 & & & 10 & 25 & & 3 \\
\hline 15 & 3 & 3 & 8 & 3 & & 8 & & & & & & 3 & & & 5 & 10 & & 3 \\
\hline 12 & 3 & 5 & 10 & 5 & 5 & 10 & 5 & & & & & 3 & 5 & & 5 & 15 & & 3 \\
\hline 12 & 3 & 5 & 8 & 10 & & 8 & 5 & & & & & 3 & 5 & & 5 & 15 & & 3 \\
\hline 25 & 5 & 3 & 15 & 10 & & 8 & 5 & & & & & 3 & 5 & & 5 & 20 & & 3 \\
\hline 20 & 3 & 5 & 10 & 10 & 5 & 5 & 5 & & & & & 5 & 5 & & 5 & 10 & & 3 \\
\hline 10 & 3 & 5 & 8 & 3 & 5 & 10 & & & & & & 3 & & & 5 & 10 & & 3 \\
\hline 8 & & 5 & 8 & 3 & 5 & 5 & 5 & & & & & & 5 & & 5 & 5 & & 3 \\
\hline 8 & & 5 & 8 & 3 & & 8 & & & & & & 3 & 5 & & 5 & 5 & & 3 \\
\hline 8 & 3 & 5 & 10 & & 5 & 5 & & & & 25 & & 3 & & & 5 & 67 & & 3 \\
\hline 10 & 3 & 5 & 8 & 5 & 5 & 10 & & & & & & 3 & 5 & & 5 & 8 & & 3 \\
\hline 10 & 3 & 10 & 10 & 5 & 5 & 5 & & & & 15 & & 3 & & & 5 & 15 & & 3 \\
\hline 5 & 3 & 5 & 15 & 3 & & 8 & 5 & & & & & 5 & 5 & & 5 & 5 & & 3 \\
\hline 5 & 8 & 5 & 8 & 3 & & 8 & 5 & & & & & & & 5 & 5 & 5 & & 3 \\
\hline 5 & 3 & & 5 & 5 & & 5 & 5 & & & & & & & & & 5 & & \\
\hline 3 & 5 & & 5 & 3 & 5 & 5 & 5 & & & & & & & & 5 & & & \\
\hline 10 & & 5 & 5 & 25 & 5 & 10 & 15 & & & & & & & & 5 & 20 & & 3 \\
\hline 5 & 20 & & & & & 5 & 5 & & & & & & & & 5 & & & \\
\hline 5 & 3 & & 5 & 5 & & & & & & & & & & & 5 & 5 & & \\
\hline 35 & 3 & 5 & 17 & 3 & & 8 & 5 & & & & & 5 & 5 & & 5 & & & \\
\hline 32 & 3 & 5 & 20 & 3 & 5 & 8 & & & & & & 5 & 5 & & 5 & 5 & & \\
\hline 30 & 3 & 5 & 19 & 5 & & 5 & 5 & & & & & 5 & 5 & & 5 & 5 & & \\
\hline 30 & 5 & 5 & 13 & 10 & & 8 & 5 & & & & & 5 & 5 & & 5 & 5 & & \\
\hline 35 & 10 & 5 & 15 & 10 & & 5 & 5 & & & & & 5 & 5 & & 5 & 5 & & \\
\hline 30 & 3 & 5 & 17 & 3 & & 8 & & & & & & 5 & 5 & & 5 & 15 & & \\
\hline 25 & 5 & 5 & 13 & 3 & 5 & 10 & 5 & & & & & 5 & 5 & & 5 & 5 & & \\
\hline 30 & 5 & 5 & 10 & 5 & 5 & 8 & 5 & & & & & 5 & 5 & & 5 & 5 & & \\
\hline 20 & 3 & 5 & 10 & 3 & 5 & 10 & & & & & & 5 & 5 & & 5 & 5 & & \\
\hline 34 & 3 & 5 & 10 & 3 & 5 & 8 & & & & & & 5 & 5 & & 5 & 5 & & \\
\hline 20 & 3 & 5 & 10 & 3 & 5 & 8 & 5 & & & & & 5 & 5 & & 5 & & & \\
\hline 15 & 3 & 5 & 10 & 3 & 5 & 8 & 5 & & & & & 5 & 5 & & 5 & 5 & & \\
\hline 20 & 3 & 5 & 10 & 5 & 5 & 8 & & & & & & 5 & 3 & & 5 & 5 & & \\
\hline 29 & 3 & 5 & 10 & 3 & 5 & 8 & & & & 56 & & 5 & & & 5 & 5 & & \\
\hline 20 & 3 & 5 & 10 & 13 & 5 & 8 & 5 & & & & & 5 & 8 & & 5 & 8 & & \\
\hline 20 & 5 & 5 & 10 & 13 & 5 & 8 & 5 & & & & & 5 & 5 & & 5 & 8 & & \\
\hline 24 & 3 & 5 & 10 & 3 & 5 & 8 & 5 & & & & & 5 & 5 & & 5 & 5 & & \\
\hline 25 & 3 & 5 & 10 & 3 & 5 & 10 & 5 & & & & & 5 & 5 & & 5 & 5 & & \\
\hline
\end{tabular}

authigenically by processes in which biogenic silica is consumed. The generally higher smectite content of the Site 505 sediments, in conjunction with the lower "amorphous scatter," suggests that the authigenic formation of smectite is enhanced at Site 505 in comparison with Site 504.

\section{Kaolinite and Illite}

Kaolinite and illite form a minor part of the claymineral fraction of most of the samples, and never more than $6 \%$ of the bulk composition. Kaolinite is restricted to the $\langle 2-\mu \mathrm{m}$ and 2 - to $20 \mu \mathrm{m}$ fractions, but naturally is more common in the clay-size fraction. Illite occurs in all of the grain size fractions, but mainly in the $<2-\mu \mathrm{m}$ fraction. In most samples, the kaolinite content exceeds that of illite, an observation also made on surface samples from the Panama Basin by Heath et al. (1974). These authors found evidence that both minerals were derived from continental sources in Ecuador, Colombia, and southern Panama. We therefore assume that both minerals found in many of the cores of the Sites 504 and 505 have the same sources. According to Heath et al. (1974), transport by water seems to be the most likely mechanism. However, eolian transport from these sources cannot be excluded, as the relatively large amount of windblown volcanic glass in the sediments of both sites suggests (Beiersdorf and Natland, this volume). The kaolinite and illite percentages often increase in the samples where the smectite percentages are also increased, supporting the assumption that some of the smectite is terrigenous.

\section{Quartz and Feldspar}

Quartz and feldspar were detected in all of the samples. They are more common in the 2- to $20-\mu \mathrm{m}$ fraction than in the other grain-size fractions, where, at Site 504, they are sometimes missing. In most of the samples, quartz is somewhat more common than feldspar, but never exceeds $12 \%$ of the bulk composition, whereas the feldspar percentages are never higher than $8 \%$. The dis- 
Table 1. (Continued).

\begin{tabular}{|c|c|c|c|c|c|c|c|c|c|c|c|c|c|c|c|c|}
\hline \multirow{2}{*}{$\begin{array}{c}\text { Lithologic } \\
\text { Units }\end{array}$} & \multirow{2}{*}{$\begin{array}{c}\begin{array}{c}\text { Marca- } \\
\text { site }\end{array} \\
>20 \mu \mathrm{m}\end{array}$} & \multicolumn{3}{|c|}{ Barite } & \multicolumn{3}{|c|}{ Sepiolite } & \multicolumn{3}{|c|}{ Opal-CT } & \multicolumn{3}{|c|}{ Clinoptilolite } & \multicolumn{3}{|c|}{$\begin{array}{l}\text { Accessory } \\
\text { Minerals" }\end{array}$} \\
\hline & & $<2 \mu \mathrm{m}$ & $2-20 \mu \mathrm{m}$ & $>20 \mu \mathrm{m}$ & $<2 \mu \mathrm{m}$ & $2-20 \mu \mathrm{m}$ & $>20 \mu \mathrm{m}$ & $<2 \mu \mathrm{m}$ & $2-20 \mu \mathrm{m}$ & $>20 \mu \mathrm{m}$ & $<2 \mu \mathrm{m}$ & $2-20 \mu \mathrm{m}$ & $>20 \mu \mathrm{m}$ & $<2 \mu \mathrm{m}$ & $2-20 \mu \mathrm{m}$ & $>20 \mu \mathrm{m}$ \\
\hline \multirow{5}{*}{ IA } & \multirow{14}{*}{3} & & 5 & & & & & & & & & & & k5 & & \\
\hline & & & 5 & & & & & & & & & & & $\mathrm{ks}$ & & d3 \\
\hline & & & 5 & & & & & & & & & & & $\mathrm{k} 5$ & & d3 t5 \\
\hline & & & 5 & & & & & & & & & & & $\mathrm{ks}$ & as & \\
\hline & & $\begin{array}{l}5 \\
5\end{array}$ & $\begin{array}{l}5 \\
8\end{array}$ & & & & & & & & & & & & & \\
\hline \multirow{11}{*}{ IB } & & 5 & 8 & & & & & & & & & & & & & \\
\hline & & & $\begin{array}{l}8 \\
5\end{array}$ & & & & & & & & & & & & & \\
\hline & & 5 & 8 & & 10 & & & & & & & & & & & \\
\hline & & 5 & 8 & & & & & & & & & & & & & 85 \\
\hline & & 5 & 8 & & & & & & & & & & & & & \\
\hline & & 5 & 5 & & & & & & & & & & & & & \\
\hline & & s & 8 & & & & & & & & & & & & & \\
\hline & & $\begin{array}{l}5 \\
5\end{array}$ & $\begin{array}{l}8 \\
8\end{array}$ & & & & & & & & & & & & & \\
\hline & & 5 & 8 & & 15 & & & & & & & & & & d3 & \\
\hline & $\begin{array}{l}5 \\
5\end{array}$ & 5 & $\begin{array}{l}8 \\
8\end{array}$ & & 15 & & & & & & & & & ks & & \\
\hline & 10 & $\begin{array}{l}5 \\
5\end{array}$ & $\begin{array}{l}5 \\
8\end{array}$ & & & & & & & & & & & & & \\
\hline \multirow{3}{*}{ IC } & & & 8 & & & & & & & & & & & $\mathrm{ks}$ & & \\
\hline & & 5 & $\begin{array}{l}8 \\
8\end{array}$ & & 15 & & & & & & & & & & & \\
\hline & & & s & & 5 & & & & & & & & & $\mathrm{ks}$ & & \\
\hline \multirow{4}{*}{ II } & & & $\begin{array}{r}5 \\
10\end{array}$ & & $\begin{array}{r}10 \\
5\end{array}$ & 5 & & & & & & & & $\mathrm{k} 5 \mathrm{ss}$ & & \\
\hline & & & 5 & & 10 & & & & & & & & & & & \\
\hline & & 5 & 8 & & & & & & & & & & & & & gs \\
\hline & & & 10 & & & & & & & & & & & ks & & \\
\hline \multirow{6}{*}{ III } & 5 & 5 & $\begin{array}{l}10 \\
10\end{array}$ & & 5 & 5 & & & & & & & & $\mathrm{ks}$ & & \\
\hline & & & 8 & 5 & & & & 67 & 58 & 74 & 5 & 5 & & & & \\
\hline & & & 5 & 5 & & & 5 & 23 & 70 & 72 & & 5 & & $\mathrm{ks}$ & & \\
\hline & & & 5 & 5 & 5 & & & 67 & 72 & 82 & 5 & 5 & & k5 & & \\
\hline & & 5 & $\begin{array}{l}10 \\
8\end{array}$ & 5 & & 10 & 10 & 32 & 32 & 25 & 5 & 10 & & ks & & \\
\hline & & & 8 & 3 & 20 & & & $\begin{array}{l}67 \\
82\end{array}$ & 85 & 87 & & & & & & \\
\hline \multirow[t]{4}{*}{1} & & & $\begin{array}{l}5 \\
5\end{array}$ & & & & & & & & 5 & & & & & \\
\hline & & & $\begin{array}{l}5 \\
5\end{array}$ & & & & & & & & . & & & & & \\
\hline & & & 5 & & & & & & & & & & & & & a.3 \\
\hline & & & 5 & & & & & & & & & & & ks & & \\
\hline \multirow[t]{6}{*}{ II } & & $\begin{array}{c}5 \\
5\end{array}$ & $\begin{array}{r}8 \\
10\end{array}$ & & & & & & & & & & & $\mathrm{ks}$ & & \\
\hline & & 5 & 10 & & & & & & & & & & & & & \\
\hline & & 5 & 8 & & & & & & & & & & & & & \\
\hline & & 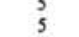 & $\begin{array}{l}10 \\
10\end{array}$ & & 10 & & & & & & & & & k5 & & \\
\hline & & 5 & 8 & & & & & & & & & & & $\mathrm{ks}$ & & a3 3 \\
\hline & & $\begin{array}{l}5 \\
5\end{array}$ & $\begin{array}{r}8 \\
10\end{array}$ & & & 5 & 10 & & & & & & & k5 & & a5 88 \\
\hline \multirow[t]{3}{*}{ III } & & 5 & 8 & & & 5 & 5 & & & & & & & 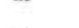 & & \\
\hline & & 5 & 8 & & & 5 & 8 & & & & & & & ks & & \\
\hline & & 5 & 10 & 3 & & 5 & 5 & & & & & & & ks & & \\
\hline
\end{tabular}

tribution diagrams (Figs. 1 and 2) show that, in general, both minerals are positively correlated, indicating the same provenance, which we believe to be mainly terrigenous. Only in Unit III of Site 504 can some of the quartz be attributed to the diagenetic formation of pore-filling chalcedony (Beiersdorf and Natland, this volume).

\section{Maghemite and Magnetite}

Maghemite occurs in all samples of the unconsolidated sediments of both sites, where it was detected in the 2- to $20-\mu \mathrm{m}$ fractions of all samples and in the $>20-\mu \mathrm{m}$ fraction of most of the samples. It is more often missing in the $>20-\mu \mathrm{m}$ fraction at Site 504 than at Site 505. At neither site does it constitute more than $6 \%$ of the bulk composition.

Magnetite forms a considerable portion of the $>20$ $\mu \mathrm{m}$ fraction of some of the samples, whereas maghemite is missing from this grain-size fraction. The $>20-\mu \mathrm{m}$ fraction is the only fraction where magnetite occurs.
Magnetite is a common constituent of ocean-floor basalts. It often is subjected to low-temperature oxidation, leading to maghemite under halmyrolitic conditions (Ade-Hall et al., 1976). Therefore, the magnetite and maghemite found in the sediments of Sites 504 and 505 probably were transported laterally to the sites from partially halmyrolitically altered submarine basalt outcropping elsewhere in the Costa Rica Rift region. The somewhat increased abundance of maghemite in the Site 505 sediments may be due to the generally rough basement topography in the surroundings of the site, with a greater potential of basalt outcrops, as seismic-reflection records show (Site 505 report, this volume).

\section{Pyrite and Marcasite}

Pyrite occurs in all of the samples of both sites; it is restricted to the 2- to $20-\mu \mathrm{m}$ and $>20-\mu \mathrm{m}$ fractions, with one exception at Site 504, where it was also detected in the $<2-\mu \mathrm{m}$ fraction. Marcasite was detected only in sed- 


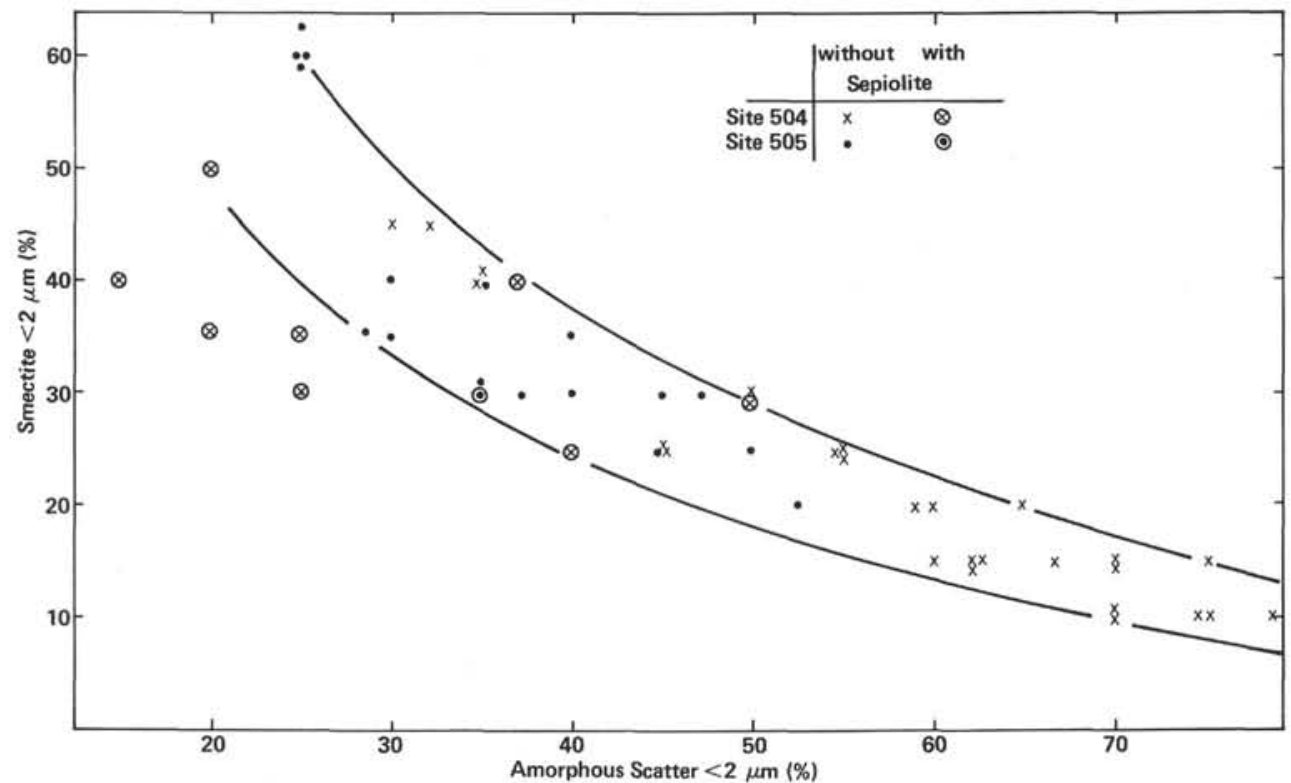

Figure 3. Correlation between amorphous scatter and smectite of the $<2-\mu \mathrm{m}$ fraction of sediments from DSDP Sites 504 and 505.

iments of Site 504, where it is restricted to sediments from Sub-unit IB downward. It is much less common than pyrite, and rarely exceeds $1 \%$ of the bulk composition. In contrast, the pyrite contents often range from 3 to $6 \%$.

A number of mechanisms have been postulated for the formation of both marcasite and pyrite. It is suggested by many authors that the sulfides are derived by reduction of sulfate in sea water, although in some cases small quantities of sulfur are thought to be obtained from organic material. Pyrite is thought to be formed through intermediate unstable iron monosulfides, mackinawite and greigite (Berner, 1967). In general, neutral to slightly acid conditions favor pyrite formation. Pyrite formation in pelagic nannofossil sediments has been interpreted to indicate rapid accumulation rates (Berger and von Rad, 1972), an interpretation in good agreement with the high accumulation rates found at Sites 504 and 505 (Beiersdorf and Natland, this volume). Marcasite has not commonly been reported from sediments of the open marine environment. It is often said to form under slightly more-acid conditions than pyrite (Edwards and Baker, 1951; Betechtin, 1957; Tröger, 1967; Rickard, 1969; Kelts, 1976). Although this has been called in question by recent experimental work (Krauskopf, 1979), comparison between the $\mathrm{pH}$ values measured on interstitial-water samples obtained from sediments of Sites 504 and 505 (Mottl, Lawrence, et al., this volume) suggests that marcasite indeed forms under more-acid conditions than pyrite generally does. The $\mathrm{pH}$ values of Site 504 decrease from about 7.5 at the top of the sequence to nearly constant values of 7.0 below 100 meters sub-bottom. The strongest decrease occurs within the upper 50-meters. The first occurrence of marcasite is at 63.50 meters (Sample 504-13-1, 70-75 cm), within the interval between 50 and 100 meters sub-bottom where $\mathrm{pH}$ values are already close to 7.0 . The $\mathrm{pH}$ values of Site 505 are generally higher than those of Site 504, and remain always above 7.1.

Experimental data obtained by Roberts et al. (1969) suggest that pyrite can form at a $\mathrm{pH}$ as low as 6.0. The $\mathrm{pH}$ values at Sites 504 and 505 are generally higher, and range between 7.0 and 7.8 , indicating that pyrite formation can take place within a fairly wide $\mathrm{pH}$ range, at least between 6 and 7.8 .

That marcasite is missing from Site 505 sediments suggests that the upper limit of the $\mathrm{pH}$ range for marcasite formation-which seems to be at $\mathrm{pH} 7.0$ or 7.1 (according to the measurements at Site 504)-is not reached yet at this site. Kelts (1976) found similarly low $\mathrm{pH}$ values in conjunction with marcasite occurrences in Miocene foraminifer nannofossil oozes from DSDP Site 315 (Leg 33, Fanning Island Fan, Line Islands). He discusses a drop in $\mathrm{pH}$ from above 7.0 to 6.0 initiated by sulfate-reducing bacterial activity which produces $\mathrm{CO}_{2}$ and $\mathrm{H}_{2} \mathrm{~S}$, leading further to calcite dissolution and thence to physicochemical conditions within the microenvironment of organic processes which favor the direct formation of marcasite.

The relatively high $\mathrm{Ca}^{2+}$ concentrations found in interstitial waters of Site 504 (Mottl, Lawrence, et al., this volume) are in agreement with this assumption. They are never lower than $9 \mathrm{mM} / 1$, and increase sharply to values above $15 \mathrm{mM} / 1$ below 100 meters sub-bottom, whereas the $\mathrm{Ca}^{2+}$ concentrations at Site 505 remain between 2.5 and $10 \mathrm{mM} / \mathrm{l}$.

It is likely that the heat flow, which is considerably higher at Site 504 than at Site 505 (Langseth et al., this volume), has led to the special conditions under which marcasite is formed at Site 504.

\section{Apatite}

Apatite was detected in all of the samples but one of Unit III of Site 504. It is most common in the grain-size 
fraction $>20 \mu \mathrm{m}$. At both sites, it never exceeds $6 \%$ of the bulk composition and likely represents mainly the considerable amount of fish debris which was recognizable in the smear slides and strewn preparations of the coarse fraction (Beiersdorf and Natland, this volume).

\section{Barite}

Barite was detected in all of the samples, with the exception of one from Unit III of Site 504. It mainly occurs in the $\langle 2-\mu \mathrm{m}$ and $2-$ to $20-\mu \mathrm{m}$ grain-size fractions. Only in the sediments of Unit III of Site 504, and in the lowermost sample of Site 505, was barite found in the $>20-\mu \mathrm{m}$ fraction as well. Because no contamination by drilling mud was possible (because of use of the hydraulic piston corer at Site 504), the barite must be natural. Goldberg and Arrhenius (1958) and von Stackelberg (1979) reported large barite crystals from pelagic clays near unconformities, where it is thought to have formed authigenically. An authigenic origin is assumed for the barite of Sites 504 and 505 as well. The barium for barite formation may have been derived from fossil organic remains by oxidation, as suggested by Church (1970) probably at the seawater/sediment interface. The barite in the $>20-\mu \mathrm{m}$ fraction of the Unit III sediments of Site 504 suggests that the advanced stage of diagenesis there has led to enlargement of the barite crystals.

\section{Sepiolite}

Sepiolite was detected in only a few samples of both sites. It occurs in all grain-size fractions, and may constitute as much as $6 \%$ of the bulk composition.

Sepiolite, a hydrated, magnesium-rich silicate, can be formed diagenetically in pore spaces of montmorillonitic clays. This diagenetic process, initiated by the interaction with magnesium-rich pore solutions, seems to require a relatively long reaction period (Füchtbauer and Müller, 1970). Our results support this: at both sites sepiolite occurs mainly in samples of early Pliocene age or older.

The paragenesis of sepiolite together with smectite \pm clinoptilolite and volcanic glass indicates the probable formation of sepiolite from montmorillonitic clays, while $\mathrm{SiO}_{2}$ could have been liberated by devitrification of volcanic glass during the same alteration process.

We note, however, that no palygorskite-a mineral that frequently coexists with sepiolite-has been detected in any of the samples. This could indicate exceptional environmental conditions that favored the formation of sepiolite, rather than palygorskite.

\section{Clinoptilolite and Opal-CT}

At Site 505, a single occurrence of clinoptilolite was found. At Site 504 clinoptilolite is restricted to the chalk-, limestone-, and chert-bearing Unit III. It occurs in the $<2-\mu \mathrm{m}$, and 2- to $20-\mu \mathrm{m}$ grain-size fractions, and forms up to $3 \%$ of the bulk composition.

Opal-CT was detected in the Unit III sediments of Site 504 only; it occurs in all grain-size fractions. It always forms 10 to $15 \%$ of the bulk composition.
According to Kastner and Stonecipher (1978), clinoptilolite consistently occurs only in sediments older than early Pliocene, even in primarily carbonate oozes. Therefore, the occurrence of clinoptilolite in the late Pleistocene sediments of Site $\mathbf{5 0 5}$ is unusual, and is thought to be due to an input of laterally reworked older sediment containing clinoptilolite. The clinoptilolite found in Unit III of Site 504, associated with calcareous and opal-CTrich sediments, likely was formed by in situ diagenetic alteration of rhyolitic glass or smectite plus (biogenic) silica, as suggested by Kastner and Stonecipher (1978). These possible precursors of clinoptilolite are common constituents of the sediments above Unit III.

Other potential precursors, such as phillipsite and basaltic glass, which may lead to the formation of clinoptilolite (Kastner and Stonecipher, 1978; Boles and Wise, 1978) can be largely excluded, because they are very rare or absent in Site 504 sediments.

The opal-CT occurrences in Unit III of Site 504 reflect the high degree of $\mathrm{SiO}_{2}$ precipitation from dissolved silica, which led to considerable chertification (Hein et al., this volume; Beiersdorf and Natland, this volume).

\section{Trace Minerals}

Six mineral phases were identified as trace components and are summarized in one column of Table 1. At both sites, they occur only sporadically, as trace minerals. Siderite, talc, amphibole, "serpentine," dolomite, and goethite do not seem to have genetic importance, nor is the analytical proof of their existence very reliable, because they occur in amounts close to the individual X-ray detection limits.

By the term "serpentine," we mean a mineral phase of the kaolinite-serpentine group, in addition to the mineral kaolinite (kandite group).

\section{CONCLUSIONS}

Minerals detected by X-ray diffraction but were not identified by microscopic determinations are the individual clay minerals, maghemite, magnetite, marcasite, barite, sepiolite, clinoptilolite, and some of the trace minerals.

Marcasite, opal-CT, and some of the trace minerals are restricted to Site 504 sediments. The only clinoptilolite occurrence at Site 505 indicates an input of laterally reworked sediment material. Opal-CT and clinoptilolite found in the chalk-limestone-chert sequence (Unit III) of Site 504 are results of in situ alteration of silica-rich sediments at an advanced stage of diagenesis of these relatively young (late Miocene) sediments, and can be attributed to the high in situ temperatures in the lower sediments, predicted from surface heat flow and measured by the heat-flow probe (Langseth et al., this volume).

The marcasite found at Site 504 indicates slightly more-acid conditions in the microenvironment of organic processes in comparison to Site 505. Though the mechanism of its formation remains largely unknown, the higher in situ temperatures of the marcasite-bearing 
sediments of Site 504 led to lower $\mathrm{pH}$ values, and therefore favored formation of marcasite.

Magnetite and maghemite are detrital, and likely were transported to the sites from halmyrolitically altered submarine basalt outcrops.

Kaolinite and illite are terrigenous. They were transported to the site either by water or by wind from sources in Middle and South America. Also, some of the smectite may be of continental origin, but a larger part of the fraction may have formed authigenically by processes in which biogenic silica is consumed.

Discrepancies between the bulk compositions of Subunits IB and IC of Site 504, determined by X-ray-diffraction analyses and smear-slide estimates (Beiersdorf and Natland, this volume) are mainly due to the high proportions of very fine $(<2 \mu \mathrm{m})$ siliceous-fossil debris in the sediments, which caused considerable resolution problems with the microscope.

\section{ACKNOWLEDGMENTS}

We are grateful to Dr. Peter Rothe (University of Mannheim, F.R.G.) and Dr. Jose J. Honnorez (University of Miami, U.S.A.) for critically reviewing the manuscript and making suggestions for its improvement.

\section{REFERENCES}

Ade-Hall, J. M., Johnson, H. P., and Ryall, P. J. C., 1976. Rock magnetism of basalts, Leg 34. In Yeats, R. S., Hart, S. R., et al., 1976. Init. Repts. DSDP, 34: Washington (U.S. Govt. Printing Office) 459-468.

Berger, W. H., and von Rad, U., 1972. Cretaceous and Cenozoic sediments from the Atlantic ocean. In Hayes, D. E., Pimm, A. C., et al., Init. Repts. DSDP, 14: Washington (U.S. Govt. Printing Office), 787-954.

Berner, R. A., 1967. Thermodynamic stability of sedimentary iron sulfides. Am. J. Sci., 265:773 785.
Betechtin, A. G., 1957. Lehrbuch der Speziellen Mineralogie: Berlin (Verlag Technik).

Boles, J. R., and Wise, W. S., 1978. Nature and origin of deep-sea clinoptilolite. In Sand, L. B. and Mumpton, F. A. (Eds.), Natural Zeolites: New York (Pergamon Press), pp. 235-243.

Church, T. M., 1970. Marine barite [PhD dissert.]. Univ. of Calif., San Diego.

Edwards, A. B., and Baker, G., 1951. Some occurrences of supergene iron sulfides in relation to their environments of deposition. $J$. Sediment. Petrol., 21:34-36.

Füchtbauer, H. and Müller, G., 1970. Sedimente und Sedimentgesteine. Sediment-Petrologie II: Stuttgart (E. Schweizerbart).

Goldberg, E. D., and Arrhenius, G., 1958. Chemistry of Pacific pelagic sediments. Geochim. Cosmochim. Acta, 13:153-212.

Heath, G. R., Moore, T. C., and Roberts, G. L., 1974. Mineralogy of surface sediments from the Panama Basin. J. Geol., 82:145-160.

Johnson, T. C., 1976. Biogenic opal preservation in pelagic sediments of a small area in the eastern tropical Pacific. Geol. Soc. Am. Bull., 87:1237-1282.

Kastner, M., and Stonecipher, S. A., 1978. Zeolites in pelagic sediments of the Atlantic, Pacific, and Indian Oceans. In Sand, L. B. and Mumpton, F. A. (Eds.), Natural Zeolites: New York (Pergamon Press), pp. 199-220.

Kelts, K. R., 1976. Marcasite in Miocene calcareous sediments from Hole 315A. In Schlanger, S. O., Jackson, E. D., et al., Init. Repts. DSDP, 33: Washington (U.S. Govt. Printing Office), 867-870.

Krauskopf, K. B., 1979. Introduction to Geochemistry: New York (McGraw-Hill).

Rickard, D. T., 1969. The chemistry of iron sulfide formation at low temperatures. Stockholm Contr. Geol., 20:67-95.

Roberts, W. M. B., Walker, A. L., and Buchanan, A. S., 1969. The chemistry of pyrite formation in aqueous solution and its relation to the depositional environment. Mineralum Deposita, 4:18-29.

Sahores, J., 1972. New improvement in routine quantitative phase analysis by X-ray diffractometry. Adv. X-Ray Anal., 16:186-197.

Tröger, W. E., 1967. Optische Bestimmung der gesteinsbildenden Mineralien: Stuttgart (Schweizerbart'sche Verlagsbuchhandlung).

von Stackelberg, U., 1979. Sedimentation, hiatuses, and development of manganese nodules: Valdivia Site VA-13/2, northern central Pacific. In Bischoff, J. L., and Piper, D. Z. (Eds.), Marine Geology and Oceanography of the Pacific Manganese Nodule Province: New York (Plenum), pp. 559-586. 